\title{
Role of Grafting Technique on the Success of Stenting Propagation of Two Rose (Rosa sp.) Varieties
}

\author{
Z. Izadi, H. Zarei, M. Alizadeh ${ }^{*}$ \\ Horticulture Department, Gorgan University of Agricultural Sciences and Natural Resources, Gorgan, Iran. \\ Email: *mahdializadeh@gau.ac.ir
}

Received January $30^{\text {th }}$, 2013; revised February $3^{\text {rd }}$, 2013; accepted April $1^{\text {st }}, 2013$

Copyright (c) 2013 Z. Izadi et al. This is an open access article distributed under the Creative Commons Attribution License, which permits unrestricted use, distribution, and reproduction in any medium, provided the original work is properly cited.

\begin{abstract}
The influence of two grafting techniques on the success of stenting (simultaneous cutting and grafting) and some ensuing growth parameters of stentlings were studied under glasshouse conditions. The Avalanch and Peach Avalanch glasshouse rose varieties were utilized as scion and grafted on $R$. manetti as rootstock. Two grafting techniques namely, splice and omega grafting methods were practiced and graft combinations were inserted in cocopeat-perlit (1:2) medium under mist system. The number of roots, longest root size, shoots and leaf numbers and successful grafting percentage were evaluated after grafting. In Avalanch/R. manetti and Peach Avalanch/R. manetti combinations, higher percentage of successful grafting was observed in the stentlings propagated via omega grafting technique. Furthermore Avalanch/R. manetti stentlings prepared by omega grafting were found to produce more number of roots, shoots and leaves and longest root size as compared to those propagated through splice grafting method. In case of Peach Avalanch/R. manetti combinations propagated via omega grafting more number of shoots was observed as compared to those propagated by splice method. However, these were not significantly different with respect to their leaf numbers. The results showed the superiority of omega grafting procedure.
\end{abstract}

Keywords: Omega Grafting; Splice Grafting; Stenting; Rootstock; Rose

\section{Introduction}

Grafting is an ancient horticultural technique that is indispensable to modern horticulture as well [1]; and exploitation of grafted seedlings has become a widespread practice in many parts of the world [2]. Rose is one of the most common garden plants all over the world. Due to its long history of cultivation and popularity, vast information exists on its breeding, cultivation, propagation and rootstock selection [3]. However, little is known about rose plant responses to various grafting methods. Presently, several grafting techniques such as side, cleft, notch, wedge, splice grafting methods are practice in horticultural crops [4]. Furthermore, degree of graft success is also affected by grafting technique [5]. A comparative study on different grafting methods in walnut revealed that modified bark grafting resulted to $100 \%$ graft success and $85 \%$ survival, while other grafting and budding methods i.e. whip, cleft, chip, patch and I-shaped, resulted in poor success and low survival. According to the

\footnotetext{
*Corresponding author.
}

mentioned study whip method was more successful than cleft and chip methods [6].

Review of the literature revealed that grafting technique may be important even in herbaceous species. For example, effects of three different grafting techniques (cleft, whip and tongue methods) on the success of grafting and yield of eggplant grafted on tomato showed that the highest success ratio (83.3\%) was attained while application of cleft grafting. The degree of success was found to be $69.7 \%$ in whip as well as tongue grafting techniques. However, there was no significant difference with regard to rootstock and scions [7].

Another study on determining a proper grafting technique for walnut cultivars in winter season showed that grafting success was higher using saddle method over omega technique $(87.7 \%$ and $38.3 \%$, respectively). Also graft failure was lower with saddle than omega method (19\% and $45.5 \%$, respectively). Such findings demonstrated that grafting method may be prerequisite to a successful grafting in walnut [5]. In the present investigation, rose response to grafting method and effect of grafting technique on success of rose stentlings were studied. 


\section{Materials and Methods}

\subsection{Glasshouse and Propagation Conditions}

The present study was carried out in September as well as June 2011, in fiber glass experimental glasshouse of the Gorgan University of Agricultural Sciences and Natural Resources, northern part of Iran. The greenhouse was WE oriented and equipped with mist system (Figure 1) as well as water cooler for adjusting balances of temperature and humidity. The mean temperature and relative humidity of mid-day during the study period were maintained at $29^{\circ} \mathrm{C} \pm 2^{\circ} \mathrm{C}$ and $70 \% \pm 5 \%$, respectively.

\subsection{Plant Materials}

One commercially important species of rose, namely, $R$. manetti was utilized as rootstock and twovarieties of cut flower, greenhouse roses (Avalanch, Peach Avalanch) were grafted as scion on it. The semi-hard wood cuttings with at least two nodes and $4.0 \mathrm{~mm}$ diameter of $R$. manetti were used as rootstock. The scions consist of a single-node and one leaf (including 2 leaflets) were collected from rose cultivars as soon as their mother plants enter to faded flower stage.

\subsection{Stenting Procedure}

The scions were selected based on the thickness of the stem rootstock. Scions then were grafted with splice and omega grafting methods onto $4.0 \mathrm{~cm}$ length cuttings of the rootstocks. Omega grafting tool and clipper were used to perform omega and splice grafting receptively (Figures 2(a) and (b)). Scions and rootstocks with an appropriate smooth cut could be grafted together with the maximum overlap of the cambium layer. Plastic tape was used for wrapping the graft union. Thedistal end of the rootstock was treated with IBA at the rate of $5000 \mathrm{ppm}$ to enhance root induction (Figures 2(c)). Immediately after grafting, all cut surfaces were thoroughly covered by horticultural grafting wax. Stentlings were rooted following

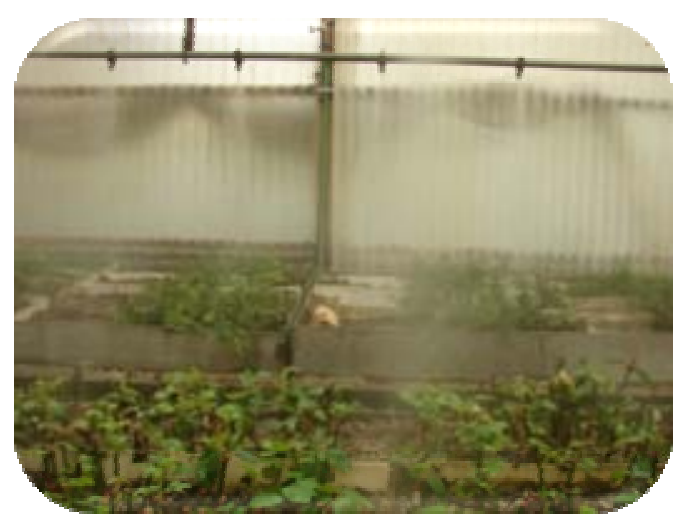

Figure 1. Mist systemin the greenhouse.

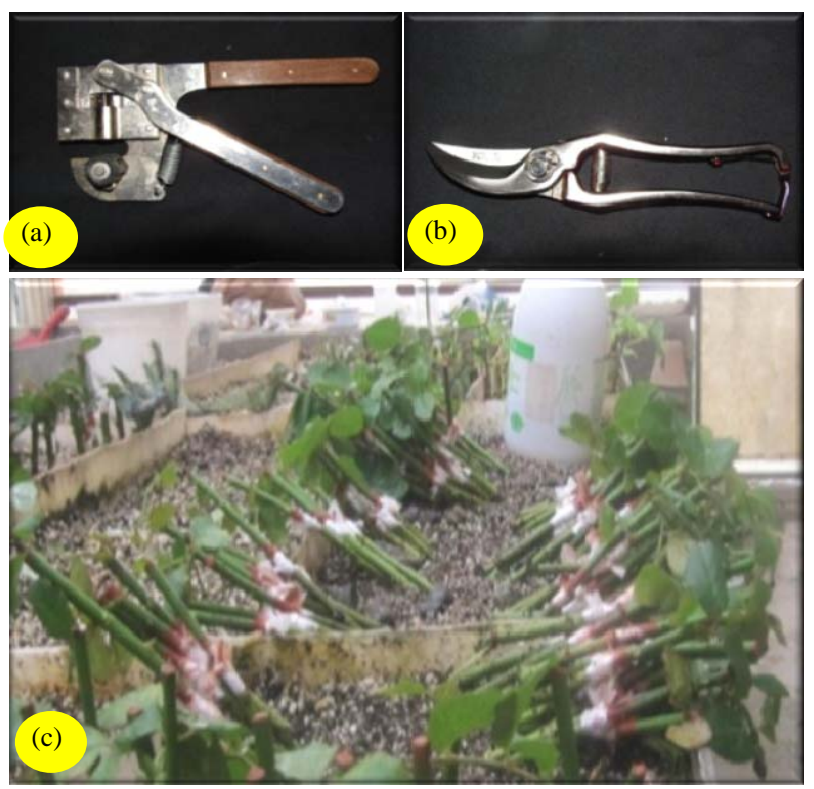

Figure 2. Omega grafting tool (a); Clipper (b); Grafted samples (stentlings) prior to insertion in rooting medium (c).

insertion in cocopeat-perlite $(1: 2)$ medium. The grafted plants were grown for 60 days under the mentioned greenhouse conditions. By the end of study grafted plants were taken out of medium and some morphological traits such as root number, root length, leaf and shoot numbers, rooting and healing percentage were recorded.

\subsection{Experimental Design}

The experiment was designed as a completely randomized design with factorial arrangement. The observations were recorded by means of three replications, each comprising 6 - 12 samples. The data were analyzed with SAS software and means were compared through Duncan test $(\mathrm{p}<0.05)$.

\section{Results and Discussion}

The influence of grafting method on morphological parameters and graft healing of stentlings are shown in Table 1. The presented data clearly revealed that successful grafting may be significantly affected by grafting method. Maximum grafting success of Avalanch $/ R$. manetti and Peach Avalanch/R. manetti was recorded in case of omega grafting procedure (64.53\% and $66.66 \%$, respectively). The stentlings of Avalanch/R. manetti propagated through omega grafting method resulted to greatest root numbers, longest root size, higher shoot and leaf numbers than those propagated through splice grafting method. Peach Avalanch $/ R$. manetti omega grafted plants produced more number of shoots but leaf number wasn't significant as compared to splice grafting method.

Grafting success is affected by method of grafting [8]. 
Table1. The effect of grafting technique on growth parameters and graft healing of rose stentlings.

\begin{tabular}{|c|c|c|c|c|}
\hline \multicolumn{5}{|c|}{ Grafting 1st time (end of September) } \\
\hline & \multicolumn{2}{|c|}{ Avalanche/R. manetti } & \multicolumn{2}{|c|}{ Peach Avalanch/R. manetti } \\
\hline \multirow[t]{2}{*}{ Measured Parameter } & \multicolumn{4}{|c|}{ Grafting method } \\
\hline & Omega & Splice & Omega & Splice \\
\hline Number of roots & $3.50^{\mathrm{a}^{*}}$ & $1.46^{\mathrm{b}}$ & $3.03^{\mathrm{b}}$ & $3.69^{\mathrm{a}}$ \\
\hline Longest root size $(\mathrm{cm})$ & $2.29^{\mathrm{a}}$ & $1.49^{\mathrm{b}}$ & $2.12^{\mathrm{b}}$ & $2.45^{\mathrm{a}}$ \\
\hline Number of shoots & $1.85^{\mathrm{a}}$ & $1.41^{\mathrm{b}}$ & $1.77^{\mathrm{a}}$ & $1.48^{\mathrm{b}}$ \\
\hline Number of leaves & $2.61^{\mathrm{a}}$ & $2.16^{\mathrm{b}}$ & $2.36^{\mathrm{a}}$ & $2.30^{\mathrm{a}}$ \\
\hline \multirow[t]{3}{*}{ Healing percentage (\%) } & $64.53^{\mathrm{a}}$ & $26.98^{\mathrm{b}}$ & $66.66^{\mathrm{a}}$ & $48.28^{\mathrm{b}}$ \\
\hline & \multicolumn{3}{|c|}{ Grafting 2nd time (first of June) } & \\
\hline & \multicolumn{2}{|c|}{ Avalanche/R. manetti } & \multicolumn{2}{|c|}{ Peach Avalanch/R. manetti } \\
\hline \multirow[t]{2}{*}{ Measured Parameter } & \multicolumn{4}{|c|}{ Grafting method } \\
\hline & Omega & Splice & Omega & Splice \\
\hline Number of roots & $3.22^{\mathrm{a}}$ & $2.83^{\mathrm{a}}$ & $3.65^{\mathrm{a}}$ & $3.31^{\mathrm{a}}$ \\
\hline Longest root size $(\mathrm{cm})$ & $3.22^{\mathrm{a}}$ & $2.48^{\mathrm{a}}$ & $2.65^{\mathrm{a}}$ & $2.65^{\mathrm{a}}$ \\
\hline Number of shoots & $1.59^{\mathrm{a}}$ & $1.07^{\mathrm{b}}$ & $1.52^{\mathrm{a}}$ & $1.13^{\mathrm{b}}$ \\
\hline Number of leaves & $2.42^{\mathrm{a}}$ & $1.78^{\mathrm{b}}$ & $2.40^{\mathrm{a}}$ & $1.86^{\mathrm{a}}$ \\
\hline Healing percentage (\%) & $48.48^{\mathrm{a}}$ & $33.33^{\mathrm{b}}$ & $48.18^{\mathrm{a}}$ & $35.73^{\mathrm{b}}$ \\
\hline
\end{tabular}

"Means in each row followed by different letters are statistically different using Duncan test $(\mathrm{p}<0.05)$.

Various grafting methods are adopted for different species, even within the same species. They have been differ in terms of required time, type of fixing method and survival percentage. The choice of grafting type within certain species could also be related to climatic conditions and to rootstock vigor. Generally, the survival rate is related to different aspects concerning plant growth phase, size and cut characteristics [9].

Several authors have described the sequence of structural events during the healing of the graft union in woody and herbaceous plants. At first step of grafting, scions and rootstocks with suitable flat cut surface may possibly be grafted together with the maximum overlap of the cambium layers. New parenchymatous cells proliferate from both stock and scion producing the callus tissue. New cambial cells differentiate from the newly formed callus, forming a continuous cambial connection between rootstock and scion. Production of new xylem and phloem thus permits the vascular connection between the scion and rootstock. For the majority of authors, this is considered as the basic requirement for a successful grafting technique [10]. On the whole, the mechanisms involved in the response are related to growth rate before grafting, tissue age, climatic conditions, rootstock leaf area, wetness of cut area, cut surface in the contact, pres- sure between cut area and number of vascular bundle in contact [9]. One of the most important stages of doing splice grafting is the fact that scion and rootstock should have the same thickness, similar angle, straight and not wavy cut surface when placed against each other [4]. In the present study, omega scissor and clipper were used for grafting. Omega grafting tool was resulted to wellmade grafting cuts, flat, smooth cut surfaces of partners that will stay together with maximum contacts as compared to splice grafting. Furthermore, larger area of cambium layer may be involved in graft healing process while application of omega grafting method. Callus formation is the first step during the graft union [11]. Cutting injury stimulates division of phloem ray cells, xylem ray, xylem parenchymal cells and parenchymal cells between periderm and phloem which results in callus formation [5]. In the present research work it was technically observed that, with the omega technique scion and rootstock were locked together with low possibility of displacement. Often it was easier to fasten tape on the grafting area with omega grafting method; however with splice grafting it was difficult. Moreover, scion and rootstock was bringing about low contacts between cambium layer and healing percentage was declined in splice method. 
Since the bench grafting procedures utilized in the present study, rooting of the stock portion also may be considered as an additional factor involved in grafting success. There were some samples with successful graft union but no root was developed by the stock (data not shown). Such samples could not be transferred to acclimation stage; therefore they were excluded from experimental data. Hence, the healing percentage shown in Table 1 represents those combinations which developed successful union as well as roots. The optimal conditions for rooting of various rose rootstocks were already optimized in our glasshouse [12], consequently, the IBA at the rate of $5000 \mathrm{ppm}$ were applied to induce root emergence.

Besides auxin application, some factors were found to be synthesized in the leaves and buds and translocated to the base of the cuttings. Carbohydrates have been considering optimal markers since they are the main energetic resource during the rooting process. The role of carbohydrates during the rooting process is controversial, but several reasons can explain their behavior. The levels of total carbohydrates and starch in the cuttings are positively related with the rooting but not through one causeeffect relationship [13]. In the present study scions were not fully defoliated and a single leaf was remained to help root induction. Buds and leaves are considered significant factors to improve root induction [4]. The influence ofbud/leaf on rooting may be related to photosynthesis, carbohydrate assimilation and phytohormone synthesis. Theauxin (indol-3-acetic acid; IAA) controls or influences most aspects of plant physiology [14] including cell division and root initiation.

The omega grafted of Avalanch/R. manetti plants, was observed to produce more, as well as longer roots (Table 1). This implies the superiority of omega technique over splice method. The omega grafted stentlings could develop better vascular connection which itself helps better carbohydrate mobilization from scion leaves to the base of rootstock. As it is clear in Table 1, omega grafted plants of Avalanch $/ R$. manetti, produced more number of shoots as well as leaves as compared to splice grafted plantlets.

In conclusion, it may be stated that omega grafting technique can be used with higher success for stentlings of rose plants as compared to splice method. Besides improvement in morphological parameters ensued grafting, the omega procedure is technically easier and faster to practice. Further assessment may be required to suggest the present rose grafting procedure in a commercial scale.

\section{Acknowledgements}

Authors are grateful to Mr. Izadi, Mr. Eteraf, Ms. Zare, Ms. Tavakoli, Ms. Mohamadnia and Ms. Mashkur for their assistance during this experiment.

\section{REFERENCES}

[1] J. Janick, S. Scofied and E. E. Goldschmit, "The History of Grafting,” Horticultural Rewiews, Vol. 35, 2010, pp. 437-439.

[2] A. Pogony, Z. Pek, L. Helyes and A. Lugasi, "Effect of Grafting on the Tomato's Yield, Quality and Main Fruit Components in Spring Forcing," Acta Alimentaria, Vol. 34, 2005, pp. 435-462.

[3] G. Niu and D. Z. Rodriguez, "Growth and Physiological Responses of Four Rose Rootstocks to Drought Stress," Journal of the American Society for Horticultural Science, Vol. 134, No. 2, 2009, pp. 202-209.

[4] H. T. Hartman, D. E. Kester and F. T. Davis, "Plant Propagation: Principles and Practices,” Prentice Hall, 2002.

[5] A. Soleimani, V. Rabiei and D. Hassani, "Effect of Different Techniques on Walnut (J. regia) Grafting,” Journal of Food, Agriculture \& Environment, Vol. 8, No. 29, 2010, pp. 544-546.

[6] Y. Ozkan and A. Gunus, "Effects of Different Applications on Grafting under Controlled Conditions of Walnut (Juglansregia L.)," Acta Horticulturae, Vol. 544, 2001, pp. 515-520.

[7] M. A. Vuruskan and R. Yanmaz, "Effect of Different Grafting Method on the Success of Grafting and Yield of Eggplant/Tomato Graft Combination,” Acta Horticulturea, Vol. 287, 1991, pp. 405-410.

[8] S. M. Paunovic, R. Miletic, M. Mitronic and D. Jankovic, "Effect of Callusing Conditions on Grafting Success in Walnut (Juglansregia L.)," Journal of Fruit and Ornamental Plant Research, Vol. 19, No. 2, 2011, pp. 5-14.

[9] F. Bekhradi, A. Kashi and M. Delshad, "Effect of Three Cucurbits Rootstocks on Vegetative and Yield of "Charleston Gray" Watermelon," International Journal of Plant Production, Vol. 5, No. 2, 2011, pp. 105-110.

[10] A. Pina and P. Erea, "A Review of New Mechanism of Graft Compatibility-Incompatibility,” Scientia Horticulturea, Vol. 106, 2005, pp. 1-11. doi:10.1016/j.scienta.2005.04.003

[11] G. Seferogulu, F. E. Tekintas and S. Ozyigit, "Determination of Grafting Union Success in 0900 Zirrat and Starks Gold Cherry Cultivars on Gisela5 and Sl64 Rootstocks,” Pakistan Journal of Botany, Vol. 36, No. 4, 2004, pp. 811-816.

[12] Z. Izadi, “An Investigation of the Effect of Grafting Time, Technique, Kind of Rootstock and Scion on the Success of Stenting Method of Greenhouse Rose (R. hybrida),” M.Sc. Thesis, Gorgan University of Agricultural Sciences \& Natural Resources, Gorgan, 2012.

[13] E. Aslmoshtaghi and A. R. Shahsavar, "Endogenous Soluble Sugars, Starch Contents and Phenolic Compounds in Easy and Difficult Toroot Olive Cuttings," Journal of Biological \& Environmental Sciences, Vol. 4, No. 11, 2010, pp. 83-86.

[14] Ch. P. Keller, M. L. Grundstad, M. A. Evanoff, J. D. Keith, D. S. Lentz, S. L. Wagner, A. H. Culler and J. D. Cohen, "Auxin Induced Leaf Blade Expansion in Arabidopsis Expansion in Arabidopsis Requires Both Wounding and Detachment," Plant Signaling \& Behavior, Vol. 6, No. 12, 1997, pp. 1997-2007. doi:10.4161/psb.6.12.18026 